\title{
GANGLIOSIDE COMPOSITION IS REGULATED DURING DIFFERENTIATION IN THE NEUROBLASTOMA $\times$ GLIOMA HYBRID CELL LINE NG108-15
}

\author{
NANCY M. DAHMS AND RONALD L. SCHNAAR ${ }^{2}$ \\ Department of Pharmacology and Experimental Therapeutics, The Johns Hopkins University School of Medicine, \\ Baltimore, Maryland 21205
}

Received August 23, 1982; Revised October 11, 1982; Accepted October 15, 1982

\begin{abstract}
Cellular differentiation of the neuroblastoma $\times$ glioma hybrid cell line NG108-15 was measured and correlated with quantitative changes in the cells' ganglioside composition. The degree of differentiation was measured using an enzymatic marker, choline acetyltransferase (CAT), which is responsible for neurotransmitter synthesis in this cell line. Differentiation of these cells is commonly induced by agents such as dibutyryl cyclic adenosine $3^{\prime}: 5^{\prime}$-monophosphate $\left(\mathrm{Bt}_{2} \mathrm{cAMP}\right)$. However, in our studies, we observed that these cells "self-differentiated," in the absence of chemical inducers, when the cells became dense in culture. The differentiation marker, CAT specific activity, rose from 150 to more than $400 \mathrm{pmol} / \mathrm{min} / \mathrm{mg}$ of protein as cell density increased, attaining a level higher than that achieved by treatment with $\mathrm{Bt}_{2}$ cAMP. Differentiation of sparse cultures could be induced by conditioned medium removed from dense cultures. This effect was not due to depletion of a serum component from the medium by the cells, since it was not mimicked by serum depletion or inhibited by addition of fresh serum to the conditioned medium. These data suggest that cell densitydependent differentiation was caused by release of a factor from the cells which induced differentiation in a concentration-dependent manner. Ganglinsides, therefore, were purified from sparse control cultures, dense cultures, and cultures treated with the differentiating agents $\mathrm{Bt}_{2} \mathrm{CAMP}$, prostaglandin $\mathrm{E}_{1}$ (plus theophylline), or butyric acid. Quantitative thin layer chromatography revealed that all of the cultures contained the four gangliosides $\mathrm{GM}_{3}, \mathrm{GM}_{2}, \mathrm{GM}_{1}$, and $\mathrm{GD}_{1 \mathrm{a}}$. The concentration of one of the gangliosides, $\mathrm{GM}_{2}$, increased markedly (up to 12 -fold) during differentiation. The $\mathrm{GM}_{2}$ concentration correlated closely with the level of CAT activity in the different cultures $(r=0.99)$. These data demonstrate that the ganglioside concentration in these cells is regulated during differentiation, a finding consistent with a possible role for gangliosides in the differentiated phenotype.
\end{abstract}

Gangliosides are found in all vertebrate tissues, but they occur at especially high concentrations in brain gray matter (Svennerholm, 1980). These plasma membrane constituents are thought to be oriented primarily in the outer membrane leaflet, with their carbohydrate portions extending into the external environment, and some studies demonstrate higher ganglioside concentrations at areas of cell-cell contact, specifically at synaptic junctions

\footnotetext{
This work was supported by National Institutes of Health Grant HD 14010 and was aided by Basil O'Connor Starter Research Grant 5302 from The March of Dimes Birth Defects Foundation. N. M. D. was supported by National Institutes of Health Training Grant GM 07445. R. L. S. is a recipient of American Cancer Society Junior Faculty Research Award JFRA-51.

We are grateful to Patti Swank for excellent technical assistance and Nancy Standish for manuscript preparation.

${ }^{2}$ To whom correspondence should be addressed.
}

(Hansson et al., 1977). For these reasons, gangliosides have been implicated in the control of intercellular interactions in the CNS and in neuronal function (Fishman and Brady, 1976; Hansson et al., 1977; Margolis and Margolis, 1979; Schachter and Roseman, 1980; Hakomori, 1981).

Although there is not direct evidence for the biological role of gangliosides, studies demonstrating quantitative changes during development in rodents (Willinger and Schachner, 1980), chickens (Dreyfus et al., 1975), and man (Svennerholm, 1974) have supported a possible role in cellular differentiation or synapse formation. Studies of nerve tissue, however, cannot distinguish between cellular differentiation or changes in relative cell populations. To address the question of the regulation of gangliosides during cellular differentiation, a homogeneous population of cells offers many advantages. To this end, analyses of gangliosides in many neuroblastoma, 
glioma, and hybrid clonal cell lines have been reported by several laboratories (Dawson, 1979; Rebel et al., 1980). The study of ganglioside regulation as it relates to development and nerve function is most useful in a cell line which: (1) differentiates functionally (as well as morphologically) under defined conditions in vitro, (2) responds biochemically to neuronal modulators (neurotransmitters and hormones) found in vivo, and (3) forms functional synapses with appropriate target cells. Since the widely studied neuroblastoma $\times$ glioma hybrid cell line NG108-15 has these properties (Hamprecht, 1977), it was chosen for our studies.

This report addresses the question of ganglioside regulation during neuronal differentiation using this cell line. Previous studies have reported the ganglioside composition of neuroblastoma cell lines, including NG108-15 cells, in the presence of putative "differentiating" agents (Dawson, 1979; Dawson et al., 1980; Rebel et al., 1980; McLawhon et al., 1981). However, in those reports differentiation was defined only as a change in cell morphology and was not correlated with a functional (biochemical) marker for differentiation. As a result, it was concluded that "sialoglycosphingolipids probably represent a poor marker for nervous cell differentiation" (Dawson, 1979). The NG108-15 cell line has the advantage that differentiation can be followed biochemically by measuring the specific activity of the enzyme responsible for its neurotransmitter synthesis, choline acetyltransferase (CAT; acetyl-CoA::choline $O$-acetyltransferase, EC 2.3.1.6), which increases 3- to 4-fold during differentiation. We report that: (1) during differentiation there is a marked (12-fold) increase in the concentration of one ganglioside, $\mathrm{GM}_{2},(2)$ the concentration of $\mathrm{GM}_{2}$ correlates very closely with the independent biochemical marker for differentiation, CAT, and (3) NG 108-15 cells grown to high density in vitro differentiate spontaneously (without added inducers) with a concomitant change in the $\mathrm{GM}_{2}$ concentration. It is our conclusion that ganglioside concentrations may be regulated during neuronal differentiation.

\section{Materials and Methods}

\section{Materials}

The following materials were purchased from the indicated sources: tissue culture media (no. 430-2100 and no. 430-1600) and calf serum (virus screened, mycoplasma tested) from Grand Island Biological Co. (GIBCO), Grand Island, NY; dibutyryl cyclic adenosine $3^{\prime}: 5^{\prime}$-monophosphate (Bt 2 cAMP), prostaglandin $\mathbf{E}_{2}$ $\left(\mathrm{PGE}_{1}\right)$, theophylline, resorcinol, $N$-acetylneuraminic acid, glucosamine hydrochloride, galactosamine hydrochloride, eserine sulfate, thymidine, hypoxanthine, aminopterin, and bovine serum albumin (BSA) from Sigma Chemical Co., St. Louis, MO; choline chloride and $\left[{ }^{14} \mathrm{C}\right]$ acetylcoenzyme $\mathrm{A}$ from International Chemical and $\mathrm{Nu}-$ clear Corp., Chemical and Radioisotope Division, Irvine, $\mathrm{CA} ;\left[{ }^{3} \mathrm{H}\right]$ glucosamine hydrochloride (catalogue number NET 190), New England Nuclear, Boston, MA; liquid scintillation fluor (ReadySolv), Beckman Instruments, Fullerton, CA; butyric acid, periodic acid, isoamyl alcohol, and $n$-butanol from J. T. Baker Chemical Co., Phil- lipsburg, NJ; and silica gel 60 thin layer chromatography (TLC) plates (catalogue number 5763) from E. Merck, Darmstadt, Federal Republic of Germany. Ganglioside standards were purified from bovine brain. Neutral glycosphingolipid standards were the kind gift of Dr. Saul Roseman, Department of Biology, Johns Hopkins University, Baltimore, MD. All other reagents were of highest available purity from standard sources.

\section{Methods}

Cell cultures. NG108-15 hybrid cells (mouse neuroblastoma clone N18TG-2 $\times$ rat glioma clone C6BU-1) were grown essentially as described previously (Nelson et al., 1976). Briefly, stock cultures (passage 15 to 28) were maintained at $36.5^{\circ} \mathrm{C}$ in $75-\mathrm{cm}^{2}$ tissue culture flasks (Corning, no. 25116) in 95\% medium 1 (Dulbecco's modified Eagle's medium (GIBCO, no. 430-2100) supplemented with sodium bicarbonate ( $44 \mathrm{~mm}$ ), thymidine (16 $\mu \mathrm{M})$, hypoxanthine $(100 \mu \mathrm{M})$, and aminopterin $(1 \mu \mathrm{M}))$ and $5 \%$ calf serum, in a humidified atmosphere of $10 \% \mathrm{CO}_{2} /$ $90 \%$ air. Cells were subcultured by removing them from the flask by agitation and reseeding at a density of 300,000 cells/flask (or as indicated). In some cultures the medium was further supplemented with one of the following differentiating agents: (1) $1 \mathrm{mM} \mathrm{Bt}_{2} \mathrm{cAMP}$, (2) a combination of $10 \mu \mathrm{M} \mathrm{PGE}_{1}$ and $1 \mathrm{~mm}$ theophylline, or (3) $1 \mathrm{~mm}$ sodium butyrate. These were added to the medium from $100 \mathrm{~mm}$ neutralized aqueous stock solutions, except $\mathrm{PGE}_{1}$ which was added from a $10 \mathrm{mM}$ ethanol solution. All media were sterilized by filtration $(0.22-\mu \mathrm{m}$ pore cellulose acetate/nitrate filters (Millipore Corp., Bedford, MA)). The media were normally replaced on the $3 \mathrm{rd}, 5 \mathrm{th}$, and 6 th day after seeding, and cells were subcultured on the 7 th day.

CAT activity. CAT activity was determined by a modification of a previously described method (Schrier et al., 1974). Depending on the density of the cells, 1 to 8 flasks were combined for each determination. The medium was removed and replaced with $10 \mathrm{ml}$ of ice-cold buffer 1 (containing (gm/liter): $\mathrm{NaCl}, 7.88 ; \mathrm{KCl}, 0.40 ; \mathrm{NaH}_{2} \mathrm{PO}_{4}$. $\mathrm{H}_{2} \mathrm{O}, 0.14 ; \mathrm{NaHCO}_{3}, 0.84 ; \mathrm{CaCl}_{2} \cdot 2 \mathrm{H}_{2} \mathrm{O}, 0.26 ; \mathrm{MgSO}_{4}$. $7 \mathrm{H}_{2} \mathrm{O}, 0.20$; glucose, 1.01; and HEPES, 5.96; $\mathrm{pH}$ adjusted to 7.4 with sodium hydroxide). The buffer was removed and replaced with a second $10-\mathrm{ml}$ aliquot of the same. The cells were dislodged by agitation, combined (when multiple flasks were used), and collected by centrifugation $\left(410 \times g, 5 \mathrm{~min}, 4^{\circ} \mathrm{C}\right)$. The supernatant was discarded and the pellet was resuspended by mild trituration in a total volume of 10 to $15 \mathrm{ml}$ of buffer 2 (containing (gm/ liter): $\mathrm{NaCl}, 8.0 ; \mathrm{KCl}, 0.20 ; \mathrm{Na}_{2} \mathrm{HPO}_{4}, 2.16 ; \mathrm{KH}_{2} \mathrm{PO}_{4}, 0.2$; and glucose, 1.0; $\mathrm{pH}$ adjusted to 7.4 with sodium hydroxide). The cells were collected by centrifugation (as above), and the supernatant was discarded. The pellets were resuspended in 1 or $2 \mathrm{ml}$ (depending on cell density) of ice-cold homogenization buffer containing $200 \mathrm{~mm}$ $\mathrm{NaCl}, 0.1 \mathrm{~mm}$ EDTA, and $10 \mathrm{~mm}$ sodium acetate $(\mathrm{pH}$ 5.0). The cells were transferred to a glass-Teflon Dounce homogenizer and were homogenized for 20 strokes. This homogenate was either directly assayed for protein and CAT (see below) or further diluted (up to 5-fold) with homogenization buffer when very high cell densities were used. 
CAT activity was determined by mixing an aliquot of cell homogenate (10 or $20 \mu \mathrm{l}$ ) with $20 \mu \mathrm{l}$ of CAT assay buffer containing $100 \mathrm{~mm} \mathrm{NaH}{ }_{2} \mathrm{PO}_{4}, 400 \mathrm{~mm} \mathrm{NaCl}, 2 \mathrm{~mm}$ EDTA, $10 \mathrm{~mm}$ choline chloride, $2 \mathrm{mg} / \mathrm{ml}$ of BSA, 0.25 mm eserine sulfate, $2 \%(\mathrm{v} / \mathrm{v}) n$-butanol, and $5 \mu \mathrm{Ci} / \mathrm{ml}$ of $\left[{ }^{14} \mathrm{C}\right.$ acetylcoenzyme A $(56.7 \mathrm{mCi} / \mathrm{mmol}, 88 \mu \mathrm{M}$ acetylcoenzyme A). The volume was adjusted to $40 \mu \mathrm{l}$ (if necessary) with homogenization buffer. Assay mixtures were transferred to a $37^{\circ} \mathrm{C}$ water bath and incubated for $10 \mathrm{~min}$ (the assay was linear for at least $20 \mathrm{~min}$ under these conditions). Ice-cold water $(1 \mathrm{ml})$ was then added, the tubes were agitated, and the diluted solutions were applied to disposable columns containing $0.5 \mathrm{ml}$ of AG 1 $\times 8$ anion exchange resin (100 to 200 -mesh, Bio-Rad Laboratories, Richmond, CA). The column was washed with $2 \mathrm{ml}$ of ice-cold water, the effluents were combined, $5 \mathrm{ml}$ of scintillation fluor were added, and radioactivity was determined using a liquid scintillation spectrometer. Counting efficiency was determined on each sample after addition of an internal standard ( $\left[{ }^{14} \mathrm{C}\right]$ toluene) and was consistently near $84 \%$. The acetylcholine production was a linear function of the volume of cell homogenate added. Protein determinations were made on aliquots (5 to 20 $\mu \mathrm{l}$ ) of the same homogenates using a modification of the method of Lowry et al. (1951). Results are expressed as picomoles of acetylcholine formed per minute per milligram of protein.

Ganglioside extraction and purification. Gangliosides were purified from NG108-15 cells by a modification of the method of Fredman (1980). 'Three to seven flasks of cells containing 5 to $20 \mathrm{mg}$ of cell protein $\left(\sim 5\right.$ to $20 \times 10^{6}$ cells) were treated as described above for the washing and collection of cells. The final centrifugations were performed in graduated glass centrifuge tubes. The resulting pellets were frozen on dry ice and stored at $-20^{\circ} \mathrm{C}$ for up to 10 days before analysis.

Cell pellets were thawed, water was added to bring the volume to $0.6 \mathrm{ml}$, the suspension was transferred to a Teflon-glass Dounce homogenizer on ice, and the cells were homogenized for 20 strokes. Methanol was added $(1.6 \mathrm{ml})$, the homogenizer was agitated, and the suspension was transferred to a $13 \times 100 \mathrm{~mm}$ test tube fitted with a Teflon-lined screw cap. Chloroform was added $(0.8 \mathrm{ml})$ and the tube was capped, vigorously agitated, and allowed to reach ambient temperature (subsequent procedures were performed at 18 to $22^{\circ} \mathrm{C}$ ). The tubes were centrifuged at $3000 \times g$ for $30 \mathrm{~min}$, the supernatant was transferred to a fresh screw-capped tube, and the pellet was re-extracted with $2 \mathrm{ml}$ of chloroform:methanol:water (4:8:3), followed by vigorous agitation. The tube was recentrifuged, the supernatants were combined, and the pellets were dried (with a stream of nitrogen) and stored for protein analysis (see below). The volume of the combined supernatants was measured, and water was added to bring the final ratio of chloroform:methanol:water to 4:8:5.6. After vigorous agitation, two phases were separated by centrifugation $(1640 \times \mathrm{g}, 10 \mathrm{~min})$, the lower phase was discarded, and the upper phase was reextracted with an equivalent volume of prepared lower phase. The upper phase was removed to a fresh test tube, evaporated under a stream of nitrogen at $40^{\circ} \mathrm{C}$, resuspended in $2 \mathrm{ml}$ of water, and dialyzed for at least $16 \mathrm{hr}$ in distilled water (two changes of 2 liters each). After dialysis, the volume of the sample was measured and aliquots were removed for total sialic acid determination or for quantitative TLC (see below). Total ganglioside sialic acid was determined by the method of Jourdian et al. (1971).

Protein pellets were redissolved by stirring with $10 \mathrm{ml}$ of $0.1 \mathrm{~N}$ sodium hydroxide. Aliquots were used for protein determination using a modification of the assay of Lowry et al. (1951).

Quantitative TLC of gangliosides. ${ }^{3}$ Based on the determination of total ganglioside sialic acid (see above), aliquots of the dialyzed gangliosides $(10$ to $70 \mathrm{nmol}$ of lipid-bound sialic acid) were evaporated to dryness (using a Speed-Vac apparatus, Savant Instruments, Inc., Hicksville, NY) and resuspended in chloroform:methanol: water $(4: 8: 3)$ at a concentration of $0.5 \mathrm{~mm}$ lipid-bound sialic acid. TLC was performed on $20 \times 20 \mathrm{~cm}$ precoated (silica gel 60) glass plates (E. Merck) which had been heated at $125^{\circ} \mathrm{C}$ for $10 \mathrm{~min}$ prior to use. An aliquot of each experimental sample $(2 \mu \mathrm{l})$ or ganglioside standard (60 to $1000 \mathrm{pmol}$ in $4 \mu \mathrm{l}$ ) was streaked (using a Hamilton syringe) on $8-\mathrm{mm}$ tracks along an origin which was 2.5 $\mathrm{cm}$ from the bottom of the cooled plate. Chromatographs were developed in tanks pre-equilibrated with chloroform:methanol:aqueous $0.25 \% \mathrm{KCl}(60: 35: 8)$. The solvent front was allowed to progress 10 to $15 \mathrm{~cm}$ beyond the origin line before plates were removed and allowed to dry. Gangliosides were visualized using the freshly prepared resorcinol reagent (27 $\mathrm{mm}$ resorcinol, $0.12 \mathrm{~mm}$ cupric sulfate in $30 \%$ concentrated hydrochloric acid). Plates were evenly sprayed with the reagent (using a Kontes Chromaflex sprayer) and rapidly covered with a clean $20 \mathrm{~cm} \times 20 \mathrm{~cm} \times 1 \mathrm{~mm}$ glass plate kept in place with metal spring clamps. The plate was heated at $125^{\circ} \mathrm{C}$ for $20 \mathrm{~min}$. After cooling, gangliosides were apparent as purple bands. Normally, no other bands were apparent on the chromatographs. After treatment with neuraminidase or formic acid, the resulting neutral glycosphingolipids appeared as brown bands. The chromatographs discolored upon exposure to air for several hours, but remained stable for months if kept covered with the glass plate. For scanning and storage of the plates, the metal spring clips were replaced with plastic tape to secure the cover plate.

Quantitation was performed using a Kontes Fiber Optic Scanner coupled with a Hewlett-Packard model 3390 A plotter-integrator. The scanner was fitted with a shortwave UV bandpass filter and a 615-nm peak phosphor disk, resulting in a source illumination band of 615 $\pm 10 \mathrm{~nm}$. The detectors were set to respond to transmitted light only, and the plate was scanned at a rate of 1.2 cmlmin. The linearity and sensitivity of this method are discussed under "Results."

Preparative isolation of NG108-15 gangliosides and identification by acid and neuraminidase treatment. Gangliosides were purified from a $12-\mathrm{ml}$ packed volume of NG108-15 cells, essentially as described above. Extrac-

\footnotetext{
${ }^{3}$ The nomenclature for the gangliosides is that of Svennerholm (1980).
} 
tion volumes were increased such that the initial extraction was performed in $240 \mathrm{ml}$ of chloroform: methanol:water (4:8:3). Other procedures were as described for the smaller preparations with volumes increased accordingly. Separation of mono- and disialogangliosides was accomplished by chromatography on DEAE-Sepharose CL-6B (Pharmacia Inc., Piscataway, NJ) as described by Fredman (1980). A solution of gangliosides purified from NG108-15 cells, containing $2 \mu \mathrm{mol}$ lipid-bound sialic acid, was applied to a $5-\mathrm{ml}$ column of resin (acetate form) in chloroform:methanol:water $(120: 60: 9)$. The column was washed with loading solvent $(5 \mathrm{ml})$ and methanol $(10 \mathrm{ml})$, and gangliosides were eluted sequentially with $10 \mathrm{~mm}$ potassium acetate in methanol (30 ml; monosialogangliosides) and then $20 \mathrm{~mm}$ potassium acetate in methanol (30 ml; disialogangliosides). The eluates were evaporated, redissolved in water $(2 \mathrm{ml})$, and dialyzed extensively against water. Portions of the fractionated gangliosides were treated further with neuraminidase or formic acid as follows. An aliquot of each ganglioside fraction containing $10 \mathrm{nmol}$ lipid-bound sialic acid was dried and resuspended in $110 \mu \mathrm{l}$ of an aqueous solution containing $91 \mathrm{~mm}$ Tris-maleate, $\mathrm{pH} 6.5,3.6 \mathrm{~mm}$ $\mathrm{CaCl}_{2}, 91 \mu \mathrm{g} / \mathrm{ml}$ of BSA, and 10 milliunits of Vibrio cholerae neuraminidase (Calbiochem-Behring Corp., La Jolla, CA). The mixture was incubated for $16 \mathrm{hr}$ at $37^{\circ} \mathrm{C}$ and processed as described below. A second aliquot of each ganglioside fraction ( $10 \mathrm{nmol}$ lipid sialic acid) was dried and resuspended in $100 \mu \mathrm{l}$ of $1 \mathrm{M}$ formic acid and heated at $100^{\circ} \mathrm{C}$ for $45 \mathrm{~min}, 10 \mu \mathrm{l}$ of $10 \mathrm{~N}$ sodium hydroxide were added, and the mixture was processed as follows. A mixture of chloroform:methanol (2:1, 2.2 ml) was added to each incubation and the mixture was applied to a Sephadex G-25 Superfine (Pharmacia) column $(1 \mathrm{ml})$ pre-equilibrated with chloroform:methanol:water $(120: 60: 9)$. The glycolipids were eluted with $5 \mathrm{ml}$ of chloroform:methanol $(2: 1)$, the combined effluents were dried and resuspended in $20 \mu \mathrm{l}$ of chloroform:methanol (1:1), and $5 \mu \mathrm{l}$ were applied to a TLC plate as described under "Methods." The lipids were subjected to TLC in chloroform:methanol:0.25\% aqueous $\mathrm{KCl}(60: 35: 8)$ and detected by resorcinol reagent spray (see above). Gangliosides stained purple and neutral glycosphingolipids stained light brown.

\section{Results}

Differentiation of the neuroblastoma $\times$ glioma hybrid cell line NG108-15: Effect of cell density. At various times after seeding, cell density was determined by measuring the amount of cellular protein per flask $\left(75 \mathrm{~cm}^{2}\right)$ and differentiation was measured by determining the CAT specific activity (pmol/min/mg of protein). In each of six separate cell density experiments, CAT specific activity rose markedly as cell density increased. The rise was nonlinear. The CAT specific activity remained constant at about $150 \mathrm{pmol} / \mathrm{min} / \mathrm{mg}$ of protein when the cell density was $20 \mu \mathrm{g} / \mathrm{cm}^{2}$ (about $1.5 \times 10^{6}$ cells $/ 75-\mathrm{cm}^{2}$ flask) or less. At higher densities the CAT specific activity increased to as high as 3 times the value for sparse cells (Fig. 1). The original plating density did not affect the relationship between final cell density and CAT specific

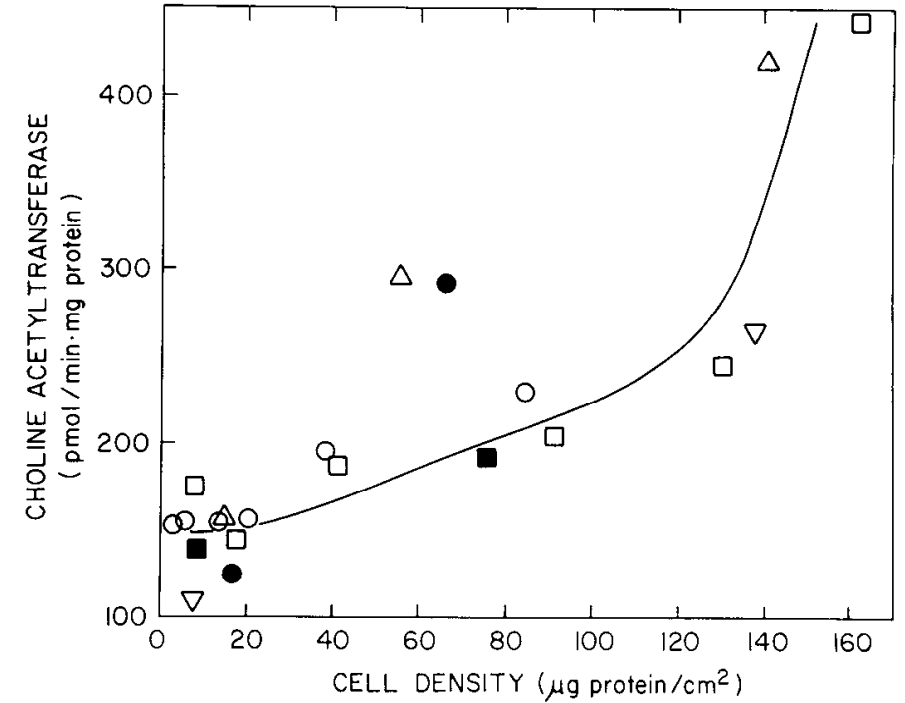

Figure 1. CAT specific activity in NG108-15 cells as a function of cell density. Cultures, seeded at densities of 2000 to 4000 cells $/ \mathrm{cm}^{2}$, were grown to the densities shown and collected for CAT and protein assays as described under "Methods." Data from six separate experiments are presented, each series represented by a different symbol. One microgram of cell protein is approximately equivalent to 1000 cells.

activity. In one experiment, for instance, cells were plated at either 1000 or 4000 cells $/ \mathrm{cm}^{2}$. Six days after plating, the sparse plate contained $21 \mu \mathrm{g} / \mathrm{cm}^{2}$ of cellular protein and had low CAT specific activity (131 pmol $/ \mathrm{min} / \mathrm{mg}$ of protein), whereas the dense plate had $56 \mu \mathrm{g} / \mathrm{cm}^{2}$ of cellular protein and a greatly increased CA'T specific activity (295 $\mathrm{pmol} / \mathrm{min} / \mathrm{mg}$ of protein). Thus, the increase in CAT specific activity correlated with the density of cells on the plate but not the time after plating.

CAT specific activity was determined as a function of cell density in control cultures and cultures chemically induced to differentiate as shown in Figure 2. Cells were plated at a density of $4000 \mathrm{cells} / \mathrm{cm}^{2}$ and were collected 4,6 , or 8 days after plating. One set of cells (control) was not treated with chemical differentiating agents. Other sets were treated for 3 days prior to each collection with either $\mathrm{Bt}_{2} \mathrm{cAMP}(1 \mathrm{mM})$, a combination of $\mathrm{PGE}_{1}(10 \mu \mathrm{M})$ and theophylline $(1 \mathrm{~mm})$, or sodium butyrate $(1 \mathrm{~mm})$. All of these agents have been reported to cause morphological and biochemical differentiation of NG108-15 cells. Cell density and CAT specific activity were compared in the different cultures. The data in Figure 2 demonstrate that when sparse cultures were used, the differentiating agents caused a marked increase in CAT specific activity compared to control. The level to which CAT activity was increased by these agents was independent of the cell density over the range tested and remained relatively constant for at least 9 days (see below). In contrast, the CAT specific activity of the control cells rose markedly as cell density increased, until the "control" cells had a higher CAT specific activity than the "differentiated" cells treated with $\mathrm{Bt}_{2} \mathrm{cAMP}$ (the most commonly used differentiating agent) or sodium butyrate, and nearly as high as cells treated with $\mathrm{PGE}_{1}$ and theophylline (Fig. 2). We conclude that dense cultures cannot serve as controls for comparing undifferentiated with differentiated cells. 


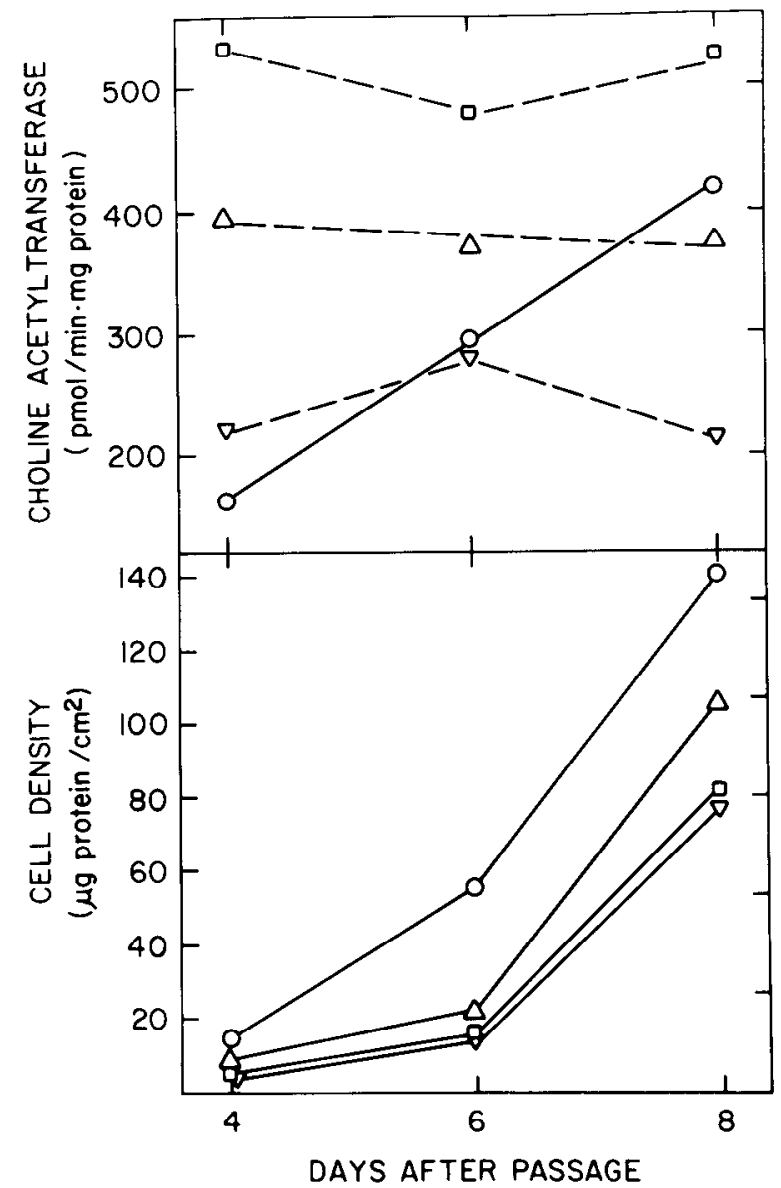

Figure 2. Effect of differentiating agents and cell density on CAT activity in NG108-15 cell cultures. Cultures were seeded at a density of 4000 cells $/ \mathrm{cm}^{2}$ in $75-\mathrm{cm}^{2}$ tissue culture flasks. Differentiating agents (see below) were added to some of the flasks 1 day after seeding, and to other flasks 3 or 5 days after seeding. Cultures were maintained in the presence of the differentiating agents for 3 days before they were collected and analyzed for CAT activity and cell density as described under "Methods." Flasks maintained in control medium (95\% medium $1,5 \%$ calf serum) were collected at the same times. All flasks were refed (with or withoul differentiating agents) on the schedule outlined under "Methods." The specific activity of CAT in the cultures (upper panel) and the cell density (lower panel) is plotted as a function of the total time in culture after seeding. Symbols are: $\bigcirc-\bigcirc$, control medium; $\nabla-\nabla$, medium containing $1 \mathrm{~mm}$ butyric acid; $\square-\square$, medium containing $10 \mu \mathrm{M} \mathrm{PGE}_{1}$ and $1 \mathrm{~mm}$ theophylline; $\triangle-\triangle$, medium containing $1 \mathrm{mM} \mathrm{Bt}_{2} \mathrm{cAMP}$.

Self-differentiation of NG108-15 cells: Conditioned medium mediates differentiation. Several explanations for self-differentiation of dense NG108-15 cells can be postulated, including: (1) direct cell-cell contact induces differentiation, (2) the release of a substance (above a critical concentration) from the cells causes differentiation, or (3) the removal of a substance from the medium (below a critical concentration) causes differentiation. In order to address these possibilities, conditioned medium from dense cultures was tested for its ability to differentiate sparse cultures as follows. The seeding of two sets of cultures of NG108-15 cells was offset by 3 days, so that medium from dense cultures (set 1) could be directly transferred to sparse cultures (set 2). Set 1 cultures were seeded at a density of 6700 cells $/ \mathrm{cm}^{2}$ and were refed with $20 \mathrm{ml}$ of complete medium (95\% medium $1,5 \%$ calf serum) on the $3 \mathrm{rd}, 5 \mathrm{th}$, and 6 th day after seeding. Three days after set 1 flasks were seeded, set 2 cultures were seeded at a density of 4000 cells $/ \mathrm{cm}^{2}$. On the 2 nd and $3 \mathrm{rd}$ days after seeding, one half of the sparse set 2 flasks were refed with fresh medium (naive) and the other half with medium removed from the dense set 1 flasks (conditioned medium). On the 4 th day after seeding, the set 2 flasks were collected and analyzed for CAT activity and cell density as described under "Methods."

Three such experiments were performed, resulting in CAT specific activity in the control (naive medium) cultures of $130 \pm 32 \mathrm{pmol} / \mathrm{min} / \mathrm{mg}$ of protein (mean \pm SD), while cultures fed with cell-conditioned medium had significantly higher CAT specific activity, $220 \pm 2$ $\mathrm{pmol} / \mathrm{min} / \mathrm{mg}$ of protein. The morphology of cells was also altered in conditioned medium, with clongation of neurites and rounding of soma apparent (data not shown). At the time of collection, the cell density of set 2 control cultures averaged $14.9 \mu \mathrm{g} / \mathrm{cm}^{2}$ while that of conditioned medium-fed cultures averaged $7.9 \mu \mathrm{g} / \mathrm{cm}^{2}$. 'The set 1 flasks from which conditioned medium was collected had the high cell density $\left(139 \mu \mathrm{g} / \mathrm{cm}^{2}\right)$ and high CAT specific activity (264 pmol/min/mg of protein) expected from such cultures.

Since removal of serum from the growth medium has been reported to cause morphological differentiation of neuroblastoma cells (Rebel et al., 1980), we tested whether the effects of conditioned medium could be (1) mimicked by lowering the serum concentration, or (2) eliminated by adding additional serum to the conditioned medium. The data are shown in Table I. Removal of

\section{TABLE I}

Effect of serum concentration on functional differentiation of NG108-15 cell cultures

Experiment 1: Cultures were seeded at a density of 1000 cells $/ \mathrm{cm}^{2}$ and maintained in culture for 3 days in complete medium ( $95 \%$ medium 1, $5 \%$ calf serum). The medium was then replaced with medium 1 supplemented to the indicated concentrations with calf serum (CS). The cultures were fed with the indicated medium periodically as described under "Methods." On the 7th day after seeding, the cells were collected and analyzed for cell density and CAT specific activity as described in the text.

Experiment 2: Sparse cultures of NG108-15 cells were treated with control medium or conditioned medium from dense flasks as described in the text. Immediately before addition of the conditioned medium to one set of the sparse cultures, additional calf serum (CS) was added as indicated. Cultures were maintained and analyzed as described in the text.

\begin{tabular}{ccc}
\hline Growth Condition & Cell Density & CAT Activity \\
\hline$\mu g$ protein $/ \mathrm{cm}^{2}$ & $\begin{array}{c}\mathrm{pmol} / \mathrm{min} / \mathrm{mg} \\
\mathrm{protein}\end{array}$
\end{tabular}

\section{Experiment 1}

Medium $1+5 \%$ CS

Medium $1+2.5 \%$ CS

48.7

Medium $1+1 \% \mathrm{CS}$

Medium $1+0.5 \%$ CS

40.7

11.1

0.87

141

Experiment 2

Medium 1 + 5\% CS

20.3

10.5

Codium (5\% CS)

11.6

\section{4}

171

100

95\% Conditioned medium, $5 \%$ fresh CS 
serum from the growth medium caused little, if any, increase in the CAT specific activity. In another experiment, additional serum $(5 \%)$ was added to conditioned medium after collection. The increase in CAT activity induced by conditioned medium $(63 \%)$ was not diminished by adding extra serum. These data are consistent with the hypothesis that conditioned medium contained a factor, released from cells, which caused NG108-15 cells to differentiale. The data cannot, however, rule out other possibilities, such as depletion of a medium component (other than a serum component), as a basis for the differentiating action of the conditioned medium. Regardless of the basis for self-differentiation, evaluation of the effect of differentiation on gangliosides in these cells required sparse control cells compared with dense cells and with cells treated with chemical differentiating agents.

Gangliosides of NG108-15 cells: Qualitative identification. The gangliosides of NG108-15 cells were identified by their migration on thin layer chromatographs and by characteristic conversions after treatment with neuraminidase or formic acid. Purified gangliosides migrate as four doublet bands (resorcinol positive) on silicic acid TLC. The doublets migrate with mobilities similar to those of bovine brain gangliosides $\mathrm{GD}_{1 \mathrm{a}}, \mathrm{GM}_{1}, \mathrm{GM}_{2}$, and $\mathrm{GM}_{3}$. Confirmations of these assignments were made as follows. Column chromatography on DEAE-Sepharose resolved the mixture into mono- and disialogangliosides. Treatment of the disialoganglioside with neuraminidase resulted in conversion to a resorcinol-positive band comigrating (as a doublet) with $\mathrm{GM}_{1}$, while treatment with formic acid resulted in a resorcinol-negative (char-positive) band co-migrating with tetraglycosyl ceramide. Treatment of the monosialogangliosides with neuraminidase resulted in the loss of only one band $\left(\mathrm{GM}_{3}\right)$ with the appearance of a new resorcinol-negative band comigrating with diglycosyl ceramide. 'Treatment with formic acid converted all components to resorcinol-negative bands which co-migrated with di-, tri-, and tetraglycosyl ceramide standards. The data are consistent with the assignments suggested above from the TIC mobilities compared to bovine brain gangliosides.

The NG108-15 cell line (Hamprecht, 1977) was developed by fusing a subclone (N18TG2) from the mouse neuroblastoma designated $\mathrm{C} 1300$ with a glioma clone (C6BU1). The original neural tumor $(\mathrm{C} 1300)$ was removed from near the spinal cord and may contain neuronal cells with central or peripheral characteristics. Since many peripheral nerves contain gangliosides of the "neolacto" series, having $N$-acetylglucosamine as the core aminosugar rather than $N$-acetylgalactosamine (Wherrett, 1976), it was of interest to establish the aminosugar structure of the NG108-15 ganglioside core. This was accomplished by metabolically labeling the gangliosides with $\left[{ }^{3} \mathrm{H}\right]$ glucosamine, purifying the gangliosides, removing the sialic acids with formic acid, and hydrolysing the core saccharides with strong hydrochloric acid (6 N HCl, $4 \mathrm{hr}, 100^{\circ} \mathrm{C}$ ). The resulting hydrolysate was chromatographed on silicic acid in a solvent (isopropanol:water:ammonium hydroxide (60:20:1)) which separated glucosamine (GlcN) from galactosamine (GalN). All of the radiolabel from the core migrated with GalN (data not shown). This is consistent with designation of the core region of the NG108-15 gangliosides as the "ganglio" series.

Taken together, the qualitative data suggest that NG108-15 cells contain gangliosides with oligosaccharide chains identical to those of brain gangliosides $\mathrm{GD}_{\mathrm{la}}, \mathrm{GM}_{1}$, $\mathrm{GM}_{2}$, and $\mathrm{GM}_{3}$. The basis for the doublet nature of the components is not known but is likely to involve differences in fatty acid and/or sphingosine chains.

Quantitation of gangliosides in NG108-15 cells: Effects of differentiation. The morphology, level of differentiation (CAT specific activity), and ganglioside patterns were compared in cells grown under five different conditions: (1) sparse controls; (2) dense controls; (3) differentiated with sodium butyrate $(1 \mathrm{mM})$ for 10 days; (4) differentiated with $\mathrm{PGE}_{1}(10 \mu \mathrm{M})$ and theophylline (1 $\mathrm{mM}$ ) for 10 days; and (5) differentiated with $\mathrm{Bt}_{2} \mathrm{cAMP}$ (1 mM) for 10 days. Photomicrographs demonstrate that the cells treated with the differentiating agents were morphologically altered (Fig. 3), with longer neurites and rounded soma typical of differentiated neuronal cells. The level of differentiation was quantitated by measuring CAT specific activity as shown in Table II. Different levels of CAT specific activity were reached, ranging from 133 (sparse controls) to 377 ( $\mathrm{Bt}_{2} \mathrm{cAMP}$-treated) $\mathrm{pmol} / \mathrm{min} / \mathrm{mg}$ of protein. Gangliosides were isolated from the cells, and the total ganglioside sialic acid is shown in Table II. Ganglioside sialic acid levels rose modestly as cell density increased (over the range tested), were unaffected by treatment with sodium butyrate, and rose sharply when cells were treated with either $\mathrm{Bt}_{2} \mathrm{cAMP}$ or with $\mathrm{PGE}_{1}$ and theophylline. The basis for these changes becomes more apparent when the individual gangliosides are quantitated after separation on TLC.

Gangliosides were quantitated from TLC plates after development with a resorcinol spray reagent, as described under "Methods." Quantitation was accomplished using a Kontes Fiber Optic Scanner coupled with a plotterintegrator (Hewlett-Packard model 3390A). This equipment allowed detection of less than $20 \mathrm{pmol}$ of sialic acid, and the assay was linear (using sialic acid standards) up to $5 \mathrm{nmol}$ (Fig. 4). Various concentrations of bovine brain monosialoganglioside $\left(\mathrm{GM}_{1}\right)$ and disialoganglioside $\left(\mathrm{GD}_{\mathrm{la}}\right)$ standards were chromatographed with experimental NG108-15 gangliosides for direct comparison and quantitation. The chromatographic separation of the gangliosides from NG108-15 cells grown under the conditions described above are shown in Figure 5, along with the densitometer tracings of the chromatographic plate. In these chromatographs, equal amounts of ganglioside sialic acid $(1 \mathrm{nmol})$ were applied to each lane (based on the values in Table II). Quantitation by the resorcinol stain after chromatography resulted in recovery (quantitation) of $96.9 \%$ of the applied lipid sialic acid, confirming the accuracy of the method. Although there were many small changes in the ganglioside pattern upon differentiation, the most consistent and dramatic alteration appeared to be a sharp increase in the relative jroportion of the ganglioside $\mathrm{GM}_{2}$.

The selective and dramatic effect of differentiation on ganglioside $\mathrm{GM}_{2}$ is even more apparent when plotted as the cellular ganglioside concentration $(\mathrm{nmol} / \mathrm{mg}$ of protein) in Figure 6. Again, while there were changes in the other gangliosides, the most marked and consistent 

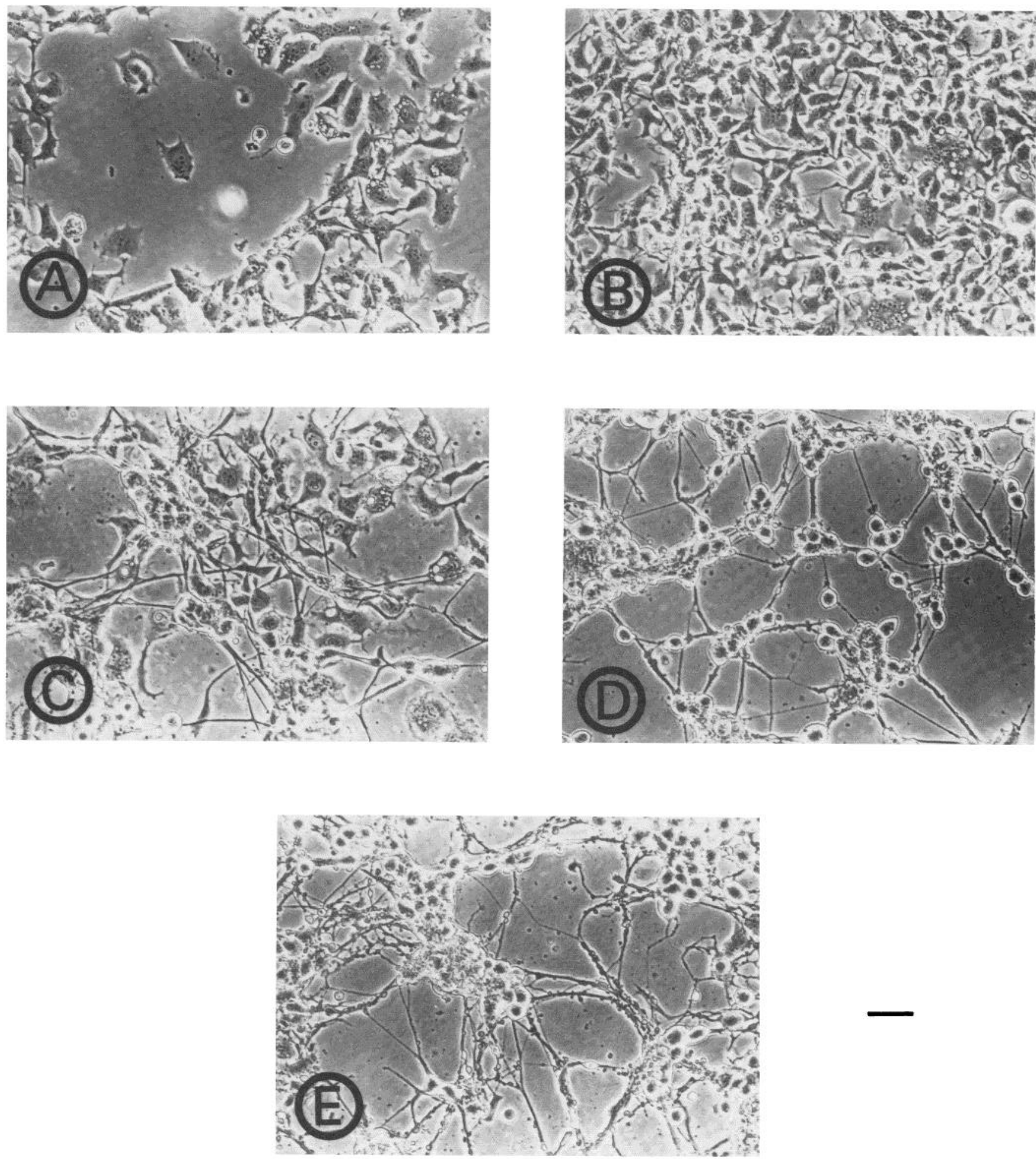

Figure 3. Photomicrographs of NG108-15 cells used for ganglioside analysis. NG108-15 cells were grown under a variety of conditions as described in the legend to Table II. Immediately before collection of the cells for analysis of CAT activity, cell density, and ganglioside composition, cultures were photographed using an Olympus IMT phase microscope fitted with an Olympus OM-2 camera body at a magnification of $\times 33$ (to the film). Conditions were as described in the legend to Table II. $A$ to $E$ correspond to sets 1 to 5 in Table II: $A$, sparse controls; $B$, dense controls; $C$, butyric acid treated; $D$, PGE 1 and theophylline treated; $E, \mathrm{Bt}_{2} \mathrm{cAMP}$ treated. Bar $=100 \mu \mathrm{m}$.

change was an increase in $\mathrm{GM}_{2}$ concentration. Over the range of differentiation tested, the $\mathrm{GM}_{2}$ concentration increased nearly 12 -fold, from 0.23 (sparse control) to $2.71\left(\mathrm{Bt}_{2} \mathrm{cAMP}\right.$-treated) $\mathrm{nmol} / \mathrm{mg}$ protein. The close re- lationship between the biochemical marker for differentiation (CAT specific activity) and ganglioside $\mathrm{GM}_{2}$ concentration is shown in Figure 7 . The correlation coefficient between these two measurements is greater than 
TABLE II

Differentiation and ganglioside content of NG108-15 cultures

NG108-15 cultures were seeded at densities of $1000 \mathrm{cells} / \mathrm{cm}^{2}$ (set 1) or 4000 cells $/ \mathrm{cm}^{2}$ (sets 2 to 5 ) in control medium (95\% medium $1,5 \%$ calf serum). Three days after seeding, the medium on sets 3 to 5 was replaced with medium containing the following differentiating agents: set $3,1 \mathrm{~mm}$ sodium butyrate; set $4,10 \mu \mathrm{M} \mathrm{PGE}_{1}$ and $1 \mathrm{mM}$ theophylline; and set 5,1 mM Bt 2 cAMP. Sets 1 and 2 were refed with control medium on the 3rd and 5th day and collected on the 6th day after seeding. Sets 3 to 5 were refed with the appropriately supplemented medium on the 6 th, 8th, 10th, and 12th day, and collected on the 13th day after seeding (the 10th day after addition of the differentiating agents). One flask of each set was photographed (see Fig. $3, A$ to $E$ ) and then analyzed for cell density and CAT activity as described in the text. Identically treated flasks were collected for ganglioside analysis ( 7 flasks, set $1 ; 3$ flasks, set 2; 5 flasks, sets 3 to 5 ). Further analysis of the ganglioside composition of these cultures is presented in Figures 5 and 6 .

\begin{tabular}{lccc}
\hline \multicolumn{1}{c}{ Growth Condition } & Cell Density & $\begin{array}{c}\text { CAT Specific } \\
\text { Activity }\end{array}$ & $\begin{array}{c}\text { Ganglioside } \\
\text { Sialic Acid }\end{array}$ \\
\hline & $\mu g$ protein $/ \mathrm{cm}^{2}$ & $\begin{array}{c}\text { pmol/min } / \mathrm{mg} \\
\text { protein }\end{array}$ & $\begin{array}{c}\text { nmol/mg } \\
\text { protein }\end{array}$ \\
1. Sparse control & 9.7 & 133 & $\mathbf{1 . 1 8}$ \\
2. Dense control & 75.3 & 190 & 4.52 \\
3. Medium + sodium & 28.9 & 303 & 3.99 \\
$\quad$ butyrate & 44.0 & 329 & 6.96 \\
$\begin{array}{l}\text { 4. Medium + PGE } \\
\text { theophylline }\end{array}$ & 60.8 & 377 & 6.25 \\
5. Medium + & & & \\
Bt & & & \\
\hline
\end{tabular}

0.99 , and during differentiation, $\mathrm{GM}_{2}$ concentration increases much more than CAT specific activity: a 3-fold increase in CAT specific activity is matched by a 12 -fold increase in $\mathrm{GM}_{2}$ concentration. In the case of the two most potent differentiating agents, $\mathrm{Bt}_{2} \mathrm{CAMP}$ and $\mathrm{PGE}_{1}$ plus theophylline, the increase in $\mathrm{GM}_{2}$ is achieved without a significant change in the concentration of the other gangliosides (Fig. 6). Thus, the increase in total ganglioside sialic acid content after treatment with these agents (of over 50\%, Table II) is realized almost completely as an increase in the one ganglioside, $\mathrm{GM}_{2}$. Sodium butyrate, which has somewhat different morphological effects (Fig. 3), and causes less of an increase in CAT specific activity (Table II and Fig. 2), has a different pattern. There is no increase in the total ganglioside sialic acid (Table II) and the marked increase in $\mathrm{GM}_{2}$ is at the expense of the other three gangliosides. The dense control cells, which show a modest increase in both CAT specific activity and total ganglioside sialic acid (Table II), appear to increase their $\mathrm{GM}_{2}$ concentration with only modest loss of $\mathrm{GM}_{3}$ and little effect on the other ganglioside concentrations. It is evident from the above data that, in this cell line, there is a marked specific change in the quantitative ganglioside pattern upon differentiation.

\section{Discussion}

Since the discovery that gangliosides exist at highest concentrations in the brain (Klenk, 1942), there has been much speculation on their potential role in the central nervous system. The diversity of ganglioside structures (Macher and Sweeley, 1978) and their preferential concentration on the outer leaflet of the plasma membrane at sites of cell-cell contact (Hansson et al., 1977) have led to their implication in cellular recognition during neu- ronal development (Fishman and Brady, 1976; Margolis and Margolis, 1979; Schachter and Roseman, 1980; Hakomori, 1981) or in synaptic transmission (Svennerholm, 1980). Yet, while gangliosides have clearly been shown to act as cell surface receptors for toxins and viruses (Holmgren et al., 1980), little is known about their physiological function in the CNS.

Although differences in ganglioside patterns have been demonstrated during development (Svennerholm, 1974; Dreyfus et al., 1975; Willinger and Schachner, 1980) and in CNS mutants (Seyfried et al., 1982), studies on the
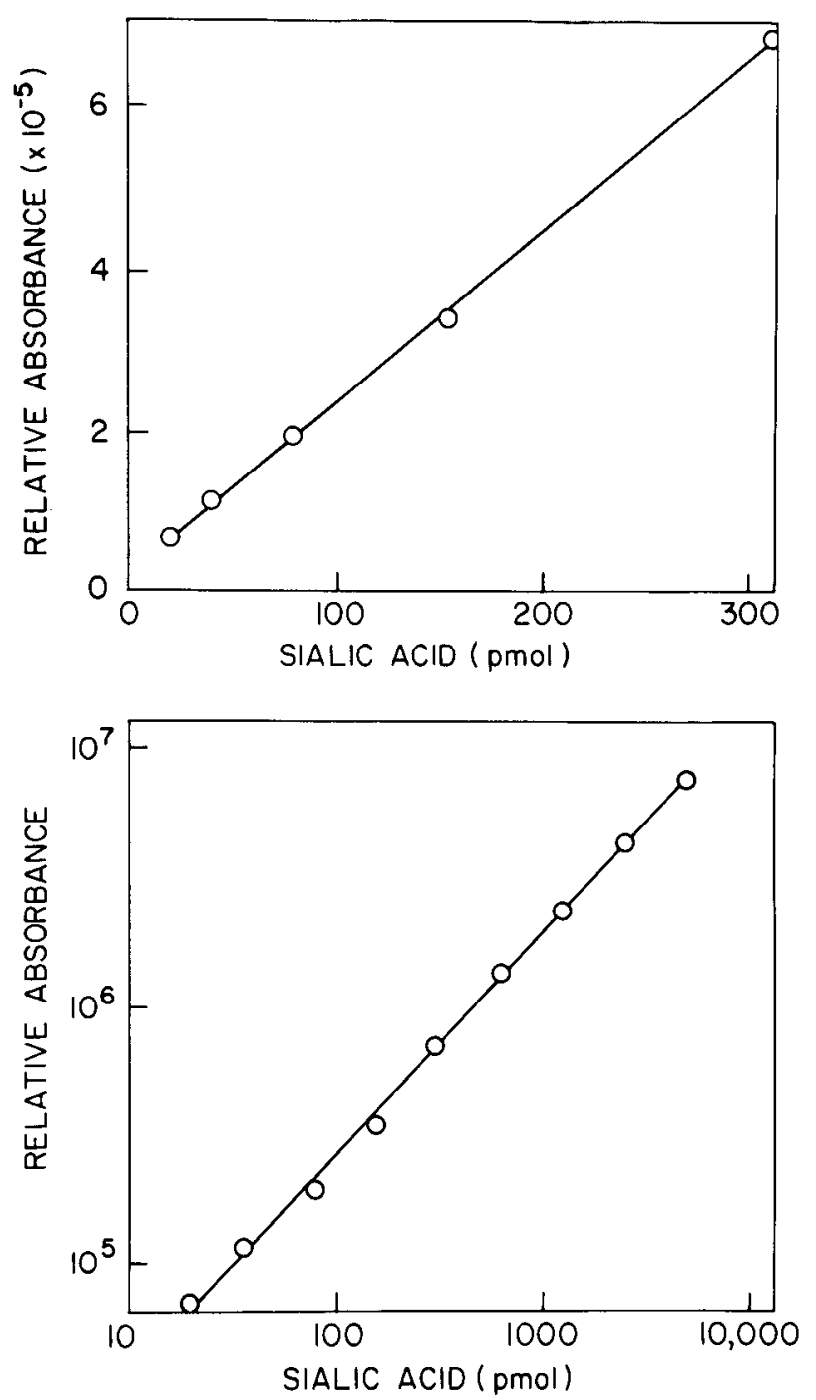

Figure 4. Quantitation of sialic acid on thin layer chromatographs. Sialic acid standards were prepared by making 2 -fold serial dilutions of a $2 \mathrm{~mm}$ stock solution of sialic acid in $95 \%$ ethanol to concentrations ranging from $1 \mathrm{~mm}$ to $3.9 \mu \mathrm{M}$. Aliquols $(5 \mu \mathrm{l})$ were streaked on TLC plates and subjected to chromatography, and the developed plates were dried and stained using a resorcinol reagent as described for gangliosides under "Methods." The resulting purple bands were scanned using a Kontes Fiber Optic Scanner with a Hewlett-Packard model $3390 \mathrm{~A}$ integrator (see the text). The relative total absorbance from the integrator is plotted versus the picomoles of sialic acid spotted on the plate (19.5 to $5000 \mathrm{pmol})$. A double log plot over the entire range is presented in the lower panel and a linear plot over the most sensitive portion of the standard curve is presented in the upper panel. 


\section{DENSITOMETER SCAN}

\section{TLC PLATE}

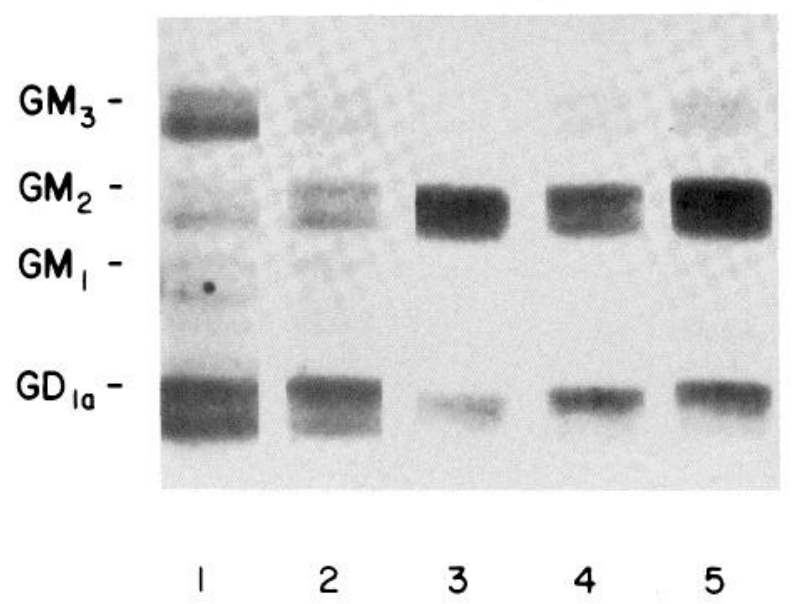

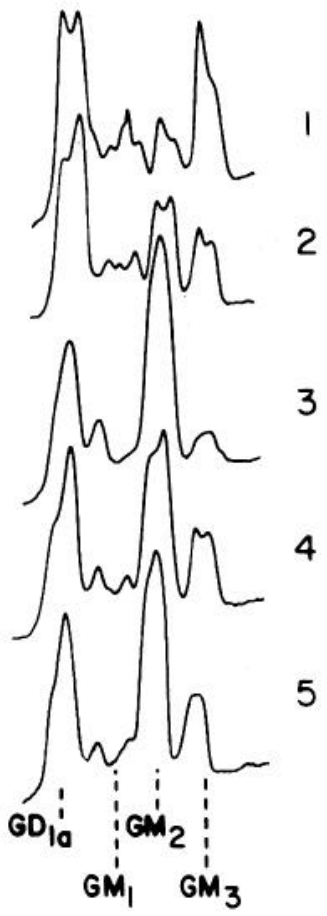

Figure 5. Thin layer chromatographs of gangliosides from control and differentiated NG108-15 cell cultures. NG108-15 cultures were maintained under the various conditions outlined in Table II. Gangliosides from the cultures were extracted, purified, and subjected to TLC as described under "Methods." Gangliosides were detected using a resorcinol reagent (see the text), and the resulting purple bands were photographed (left) and subjected to densitometric scanning (right). The migration positions of standard bovine brain gangliosides are indicated. The numbers on the lanes and scans refer to the conditions described in Table II: 1 , sparse controls; 2 , dense controls; 3 , butyric acid treated; $4, \mathrm{PGE}_{1}$ and theophylline treated; and 5 , Bt $2 \mathrm{cAMP}$ treated. Photomicrographs of the cultures before collection are presented in Figure 3.

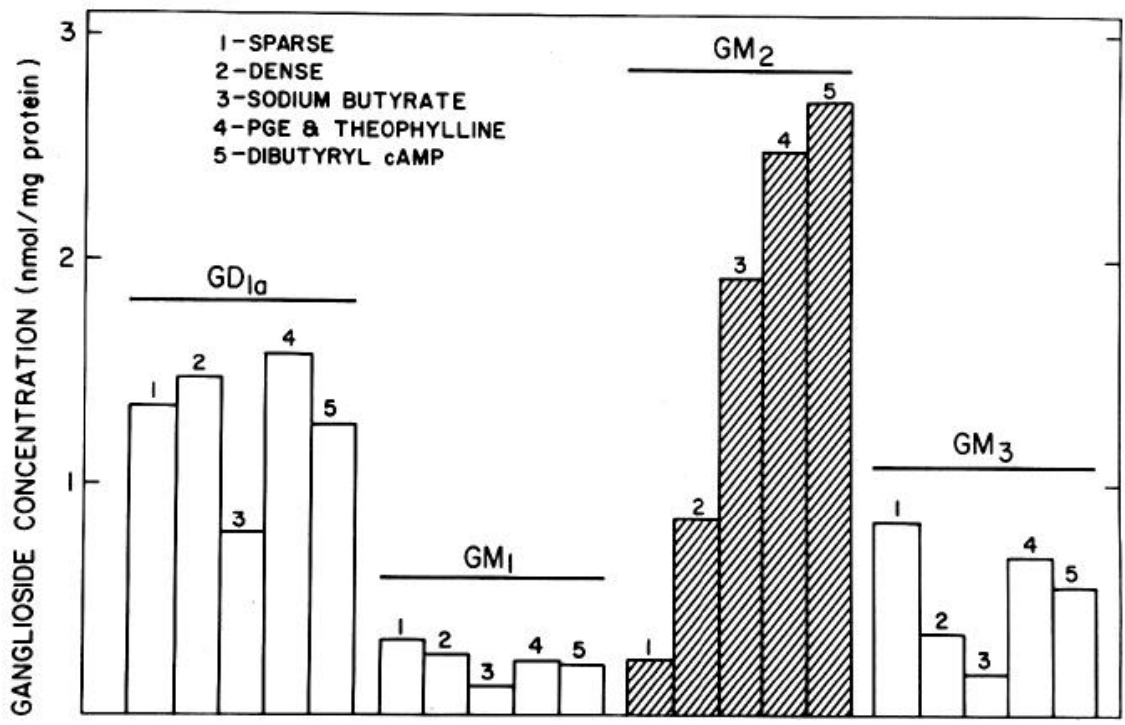

Figure 6. Quantitation of gangliosides in NG108-15 cultures. NG108-15 cultures were maintained under the various conditions outlined in Table II. The gangliosides were analyzed as described in the text. The concentration of each of the four gangliosides under each condition was calculated by densitometric scanning (Fig. 5) and total sialic acid determination (Table II). The numbers above the bars refer to the conditions described in Table II, as indicated.

function of gangliosides are hampered by the cellular complexity of CNS tissue. A change in ganglioside patterns may reflect functional changes associated with cellular differentiation or may signal a change in the relative abundance of cell types in the CNS. To circumvent this problem, homogeneous clonal cell lines derived from neural tissue have been used. These have included neuroblastoma, glioma, and hybrid cell lines (Dawson, 1979; 
Rebel et al., 1980). The neuronal cell lines examined characteristically have mono- and disialogangliosides, but none of the more complex ganglioside species. Some of these lines "differentiate" upon addition of any of several chemical agents $\left(\mathrm{Bt} \mathrm{t}_{2} \mathrm{cAMP}\right.$, sodium butyrate, $\mathrm{PGE}_{1}$, dimethyl sulfoxide, etc.) or upon serum withdrawal. In response to such "differentiation," some studies have reported variable changes in ganglioside patterns depending on the cell line used, while others have reported few differences.

However, "differentiation" in those studies was defined primarily by morphological changes. Data from our studies demonstrated that morphological criteria alone can be inaccurate as indicators of functional differentiation. Cultures grown in a serum-depleted medium $(0.5 \%$ serum) underwent morphological "differentiation": rounding of the soma accompanied by extension of long, branched neurites with distinct varicosites (data not shown). However, CAT specific activity was decreased $30 \%$ by serum depletion. Clearly, biochemical markers must be measured to establish functional differentiation. Therefore, gangliosides were quantitated in NG108-15 cells grown under a variety of conditions and compared with the CAT activity in the cultures.

The NG108-15 cell line has been studied extensively, and the following changes have been demonstrated after differentiation with $\mathrm{Bt}_{2} \mathrm{CAMP}$ or with $\mathrm{PGE}_{1}$ and theophylline (Daniels and Hamprecht, 1974; Christian et al., 1977; Hamprecht, 1977; Nelson et al., 1978; McGee et al., 1979): (1) cell size increases and proliferation decreases, (2) many long, large neurites appear, (3) the number of large $(600 \AA)$ clear intracellular vesicles increases, (4) membrane excitability is enhanced, (5) specific activities of CAT and acetylcholinesterase increase, $(6)$ the inter-

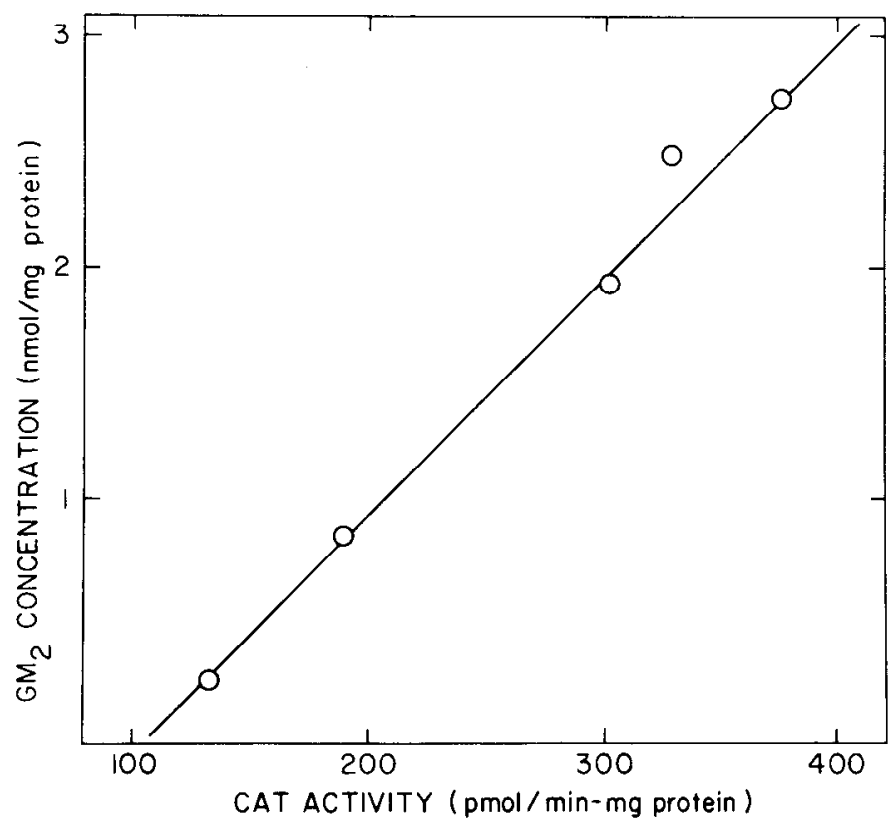

Figure 7. Correlation between ganglioside $\mathrm{GM}_{2}$ concentration and CAT specific activity in NG108-15 cultures. Values for ganglioside $\mathrm{GM}_{2}$ concentration in NG108-15 cultures grown under a variety of conditions (Fig. 6) were plotted against the CAT specific activity of those cultures (Table II). The correlation coefficient $(r)$ is greater than 0.99 . nal concentration of acetylcholine increases, $(7)$ the cells gain the ability to release acetylcholine in response to depolarization, and (8) the cells can form functional synapses with muscle cells in vitro. Therefore, differentiation of these cells causes appropriate functional as well as morphological changes, and differentiation can be quantitated by measurement of CAT specific activity.

During our initial studies it became apparent that the CAT specific activity in control, "undifferentiated" cultures increased markedly as the cell density increased (Fig. 1). The data in Figure 2 suggest that dense control cultures self-differentiate to a level as high as cells treated with $\mathrm{Bt}_{2} \mathrm{cAMP}$. These data have two implications: (1) for the current studies, cells treated with differentiating agents must be compared with sparse control cultures, and (2) previous studies comparing undifferentiated and differentiated cells should be evaluated in terms of the cell density of the control cultures.

Three sets of experiments were performed to clarify the basis for the self-differentiation of the dense cultures. These data demonstrated that differentiation could be induced by conditioned medium from dense cultures, but was not due to depletion of serum components. It appears likely that the NG108-15 cells produce a factor which induces differentiation after reaching a critical concentration in the medium.

The qualitative ganglioside composition of the NG10815 cells was determined by chromatography coupled with enzymatic and chemical degradation. In addition, the "core" aminosugar was identified after strong acid hydrolysis. The data suggest that: (1) all of the species have the common gangliotetraglycosylceramide core (containing GalNAc as the core hexosamine) typical of brain gangliosides, (2) there are four major gangliosides $\left(\mathrm{GM}_{3}\right.$, $\mathrm{GM}_{2}, \mathrm{GM}_{1}$, and $\mathrm{GD}_{\mathrm{la}}$ ), and (3) each ganglioside exists as multiple species probably due to differences in the ceramide portion. These data are in general agreement with previous studies on this cell line (Dawson et al., 1980).

Five culture conditions were chosen for evaluation of the relationship between ganglioside concentrations and differentiation (Table II). The conditions resulted in CAT specific activities in the cultures ranging from 133 to $377 \mathrm{pmol} / \mathrm{min} / \mathrm{mg}$ of protein. Sensitive and accurate quantitation of the gangliosides purified from these cultures was accomplished by scanning resorcinol-treated plates with a Kontes Fiber Optic Scanner (Figs. 4 and 5). The results indicated that one particular ganglioside, $\mathrm{GM}_{2}$, was increased markedly with differentiation (Fig. $6)$ and correlated closely $(r=0.99)$ with the CAT specific activity (Fig. 7). Under conditions of maximum differentiation ( $\mathrm{Bt}_{2} \mathrm{cAMP}$ ), a 3 -fold increase in CAT specific activity was matched by a 12 -fold increase in $\mathrm{GM}_{2}$ concentration. This was accomplished without a significant decrease in the concentrations of the other gangliosides. It appears that the concentration of $\mathrm{GM}_{2}$ is closely regulated and is linked to the state of differentiation in these cells.

Although these data do not demonstrate a functional role for gangliosides in the differentiated phenotype, the marked quantitative change reported is the minimum requirement for such a role. A major advantage of using NG108-15 cells is that a large number of functional studies have documented the neuronal characteristics of 
the differentiated cells (Daniels and Hamprecht, 1974; Hamprecht, 1977; Christian et al., 1977; Nelson et al., 1978; McGee et al., 1979). Studies can now be directed toward an understanding of the possible role of the ganglioside change reported here in these neuronal functions.

In addition to the functional significance of the reported change in ganglioside pattern, other questions remain unanswered. The enzymatic basis for the increased level of $\mathrm{GM}_{2}$ is not known. McLawhon et al., (1981), using the neuroblastoma clone N4TG1, have demonstrated that the transferase responsible for $\mathrm{GM}_{2}$ synthesis, UDP-GalNAc: $\mathrm{GM}_{3}, N$-acetylgalactosiminyltransferase, increased upon treatment with agents which increased intercellular cAMP levels. Although the chemical differentiating agents used in our studies $\left(\mathrm{Bt}_{2} \mathrm{cAMP}\right.$, $\mathrm{PGE}_{1}$, sodium butyrate) have been shown to increase cAMP levels in NG108-15 cells, and differentiated characteristics (acetylcholine storage and release, synapse formation) are increased by these agents, biochemical markers for differentiation do not correlate closely with steady state cAMP levels (Steven P. Wilson, personal communication). Nevertheless, an increase in the cellular cAMP level may be the central determinant of many of the cell's differentiated properties, including the $\mathrm{GM}_{2}$ concentration. Whatever changes occur in glycolipid glycosyltransferases or glycosidases after differentiation must be selective, since the concentration of $\mathrm{GM}_{2}$ changes dramatically without concomitant changes in other ganglioside concentrations. Only further experiments with this cell line will clarify the biochemical mechanism involved.

In summary, the ganglioside composition of NG108-15 cells has been shown to vary in a marked and predictable manner during functional cellular differentiation. The ability of these differentiated cells to produce and store neurotransmitter, to release it upon depolarization, to respond to various neurotransmitters and neurohormones, and to form functional synapses with appropriate target cells affords a unique opportunity to study the potential role of the reported ganglioside change in these various neuronal functions.

\section{References}

Christian, C. M., P. G. Nelson, J. Peacock, and M. Nirenberg (1977) Synapse formation between two clonal cell lines. Science 196: 995-998.

Daniels, M. P., and B. Hamprecht (1974) The ultrastructure of neuroblastoma glioma somatic cell hybrids. J. Cell Biol. 63: 691-699.

Dawson, G. (1979) Regulation of glycosphingolipid metabolism in mouse neuroblastoma and glioma cell lines. J. Biol. Chem. 254: $155-162$.

Dawson, G., R. McLawhon, and R. J. Miller (1980) Inhibition of sialoglycosphingolipid (ganglioside) biosynthesis in mouse clonal lines N4TG1 and NG108-15 by $\beta$-endorphin, enkephalins, and opiates. J. Biol. Chem. 255: 129-137.

Dreyfus, H., P. F. Urban, S. Edel-Harth, and P. Mandel (1975) Developmental patterns of gangliosides and of phospholipids in chick retina and brain. J. Neurochem. 25: 245-250.

Fishman, P. H., and R. O. Brady (1976) Biosynthesis and function of gangliosides. Science 194: 906-915.
Fredman, P. (1980) Isolation and separation of gangliosides on a new form of glass bead ion exchanger. In Structure and Function of Gangliosides, L. Svennerholm, P. Mandel, H. Dreyfus, and P. -F. Urban, eds., pp. 23-31, Plenum Press, New York.

Hakomori, S. -I. (1981) Glycosphingolipids in cellular interaction, differentiation, and oncogenesis. Annu. Rev. Biochem. 50: $733-764$.

Hamprecht, B. (1977) Structural, electrophysiological, biochemical, and pharmacological properties of neuroblastomaglioma cell hybrids in cell culture. Int. Rev. Cytol. 49: 99-170.

Hansson, H. -A., J. Holmgren, and L. Svennerholm (1977) Ultrastructural localization of cell membrane $\mathrm{GM}_{1}$ ganglioside by cholera toxin. Proc. Natl. Acad. Sci. U. S. A. 74: 37823786 .

Holmgren, J., H. Elwing, P. Fredman, O. Strannegard, and L. Svennerholm (1980) Gangliosides as receptors for bacterial toxins and sendai virus. In Structure and Function of Gangliosides, L. Svennerholm, P. Mandel, H. Dreyfus, and P. -F. Urban, eds., pp. 453-470, Plenum Press, New York.

Jourdian, G. W., L. Dean, and S. Roseman (1971) The sialic acids. I. Biol. Chem. 246: 430-435.

Klenk, E. (1942) Uber die Ganglioside, eine neue Gruppe von zuckerhaltigen Gehirnlipoiden. Hoppe Seylers Z. Physiol. Chem. 273: 76-86.

Lowry, O. H., N. J. Rosebrough, A. L. Farr, and R. J. Randall (1951) Protein measurement with the Folin phenol reagent. J. Biol. Chem. 193: 265-275.

Macher, B. A., and C. C. Sweeley (1978) Glycosphingolipids: Structure, biological source, and properties. Methods Enzymol. 50: 236-251.

Margolis, R. U., and R. K. Margolis (1979) Perspectives and functional implications. In Complex Carbohydrates of Nervous Tissue, R. U. Margolis and R. K. Margolis, eds., pp. 377386, Plenum Press, New York.

McGee, R., P. Simpson, C. Christian, M. Mata, P. Nelson, and M. Nirenberg (1979) Regulation of acetylcholine release from neuroblastoma $\times$ glioma hybrid cells. Proc. Natl. Acad. Sci. U. S. A. 75: 1314-1318.

McLawhon, R. W., G. S. Schoon, and G. Dawson (1981) Possible role of cyclic AMP in the receptor-mediated regulation of glycosyltransferase activities in neurotumor cell lines. J. Neurochem. 37: 132-139.

Nelson, P., C. Christian, and M. Nirenberg (1976) Synapse formation between clonal neuroblastoma $\times$ glioma hybrid cells and striated muscle cells. Proc. Natl. Acad. Sci. U. S. A. 73: $123-127$.

Nelson, P. G., C. N. Christian, M. P. Uaniels, M. Henkart, P. Bullock, D. Mullinax, and M. Nirenberg (1978) Formation of synapses between cells of a neuroblastoma $\times$ glioma hybrid clone and mouse myotubes. Brain Res. 147: 245-259.

Rebel, G., J. Robert, and P. Mandel (1980) Glycolipids and cell differentiation. In Structure and Function of Gangliosides, L. Svennerholm, P. Mandel, H. Dreyfus, and P.-F. Urban, eds., pp. 159-166, Plenum Press, New York.

Schachter, H., and S. Roseman (1980) Mammalian glycosyltransferases. In The Biochemistry of Glycoproteins and Proteoglycans, W. J. Lennarz, ed., pp. 85-160, Plenum Press, New York.

Schrier, B. K., S. H. Wilson, and M. Nirenberg (1974) Cultured cell systems and methods for neurobiology. Methods Enzymol. 32: 765-788.

Seyfried, T. N., R. K. Yu, and N. Miyazawa (1982) Differential cellular enrichment of gangliosides in the mouse cerebellum: Analysis using neurological mutants. J. Neurochem. 38: 551559.

Svennerholm, L. (1974) Sphingolipid changes during develop- 
ment. Mod. Probl. Paediatr. 13: 104-115.

Svennerholm, L. (1980) Gangliosides and synaptic transmission. In Structure and Function of Gangliosides, L. Svennerholm, P. Mandel, H. Dreyfus, and P. -F. Urban, eds., pp. 533-544, Plenum Press, New York.

Wherrett, J. R. (1976) Gangliosides of the lacto-n-glycaose series (glucosamine containing gangliosides). In Glycolipid Methodology, L. A. Witting, ed., pp. 215-232, American Oil Chemists' Society Press, Champaign, IL.

Willinger, M., and M. Schachner (1980) GMl ganglioside as a marker for neuronal differentiation in mouse cerebellum. Dev. Biol. 74: 101-117. 